\title{
Parentification, Neglect and Abandonment in Egya E. Sule's Sterile Sky
}

\author{
Lacirda Jones Nowa
}

Department of English, Chancellor College, University Of Malawi, Malawi

\begin{abstract}
Ethno-religious crises have caused so much havoc in many African countries leading to loss of lives and property. They have also rendered fear and instability among people. Specifically, this article focuses on Nigeria's experience to the ugliness of the crises through Sterile Sky a text that depicts the evil nature of the ethno religious violence in one of Nigeria's city states, Kano and how this affects the children as witnesses and/or victims to such. Through trauma and narratology this article explores Egya E. Sule's Sterile Sky from the angle of parentification, neglect and abandonment which are interconnected with the violence. Against this background it is argued that the novel depicts Murtala as a parentified child who is physically and psychologically crushed but has the agency to make constructive decisions that will help change his life for the better even in the face of abandonment.
\end{abstract}

Keywords—abandonment, ethno-religious violence, liminality, parentification, poverty.

\section{INTRODUCTION}

Many African countries have suffered a lot due to ethnoreligious crises. One of the mostly affected is Nigeria which due to the unending ethno-religious crises has experienced the loss of many lives and property. Fear and instability is also the order of the day among people in some Nigerian states and cities. This echoes what Tagurum et al (2015) stipulate that, "Nigeria, as a country has a variety of low grade conflicts that result in chronic bloodletting without the country actually being in an open state of war" (1). What this entails is that people are involved in violent acts in the name of ethnicity and religion regardless of who gets hurt. In view of this, various authors have also taken it upon themselves to write on issues related to ethno-religious crisis in different parts of Nigeria. Among them is Egya E. Sule who in his novel Sterile Sky focuses on the ethno-religious crisis in the northern part of Nigeria, Kano in particular. Adebore (2013) in her review of Sterile Sky says that "the text is set in the city of Kano in the nineties which was known for its endless religious violence which left many dead or wounded, houses burnt and a general feeling of distress on its masses" (1). This assertion is analysed in this article to appreciate how Sule uses the ethno-religious background in Nigeria's Northern states and cities in particular such as Kano as a basis for Sterile Sky and how well the crisis is interpreted in the text. As much as all this is true, it can be seen that through all this parentification is prominent especially when one looks at Murtala's life in the crisis and later abandonment by his father. Parentification is considered to be a type of role reversal, as it refers to "the broader category of relational disturbances in which an adult looks to the child to fulfil unmet needs for intimacy, parenting, or socialization by expecting the child to take on the role of partner, parent, or peer" (Engelhardt, 2012, p.50). According to Boszormenyi-Nagy and Spark (as cited in Engelhardt, 2012) parentification is "a ubiquitous and important aspect of most human relationships" (p.50). Hence, it is important to analyse this aspect in order to assess its impact on the child focaliser in the text. All these ideations will be read through trauma theory and narratology. Specifically the focus is on the concept of post-traumatic stress disorder (PTSD) and its manifestation in the experiences that the children have in the text. Besides, narratology will also be used in order that better understanding of relations between the narrator and the story in the given narrative is conveyed. Thus, an insight on how narration affects the way in which the story is told on the narrator, the writers, as well as the readers will be given.

\section{PARENTIFICATION AND VIOLENCE}

Parentification implies the phenomenon or the process of becoming a parentified child. According to Mark Karpel (1977), "it involves subjective distortion of a parent-child relationship through wishful fantasy or dependent 
behaviour of the parent" (cited in Tam, 2009, p.1). It also refers to the process through which children are assigned the role of an adult, "taking on both emotional and functional responsibilities that are typically performed by the parent. The parent, in turn, takes the dependent position of the child in the parent-child relationship" (Engelhadt 2012, p. 45). The term "parentification" was first utilized in depth by Boszormenyi-Nagy and Spark (as cited in Engelhadt, 2012, p. 45) to describe:

a common component of relationships whereby parental characteristics are projected onto an individual. Within the parent-child relationship, this process is often seen when the child performs chores or occasionally offers emotional support for a parent, and is believed to be healthy for the child as he or she begins to see the potential for him or herself in an adult role.

Parentification occurs in two levels: instrumental and emotional. Instrumental parentification refers to "the physical help that a child may provide to his or her parent by completing tasks around the home that are typically reserved for adults such as grocery shopping, doing the laundry, and cleaning the house" (Hooper, 2011, p.228). Emotional parentification on the other hand refers to "the expressive support that a parentified child may offer to his or her parent or sibling. For instance, serve as confidante, peacemaker" (Hooper, 2011, p. 228). However, emotional parentification is more harmful as compared to instrumental parentification. This is so as it involves roles that are more stressful for one to perform. This situation works hand in hand with aspects of abandonment and neglect. This is a form of child abuse as it harms the child who is overburdened with responsibility, thereby depriving them of the structure they need to survive. A parentified child takes on responsibilities that are not suitable for their age and life experiences, often creating frustration, stress, and feelings of being overwhelmed. Neglect and abandonment often lead to parentification which makes these concepts connected in one way or another.

Abandonment and neglect are most of the times intertwined with poverty. What this means is that due to lack of certain basic needs in life, one can relate to the situation differently as compared to others. Whilst some think and act positively, others react negatively. The disheartening thing though is the effect the decisions made by parents or guardians affect children. Poverty in isolation is not easy to define. This is so since it has multiple interlocking dimensions. For some it only involves material things but for others it includes the feeling of helplessness, powerlessness and voicelessness. Thus, while ISSN: 2456-7620 poverty is "material in nature, it has psychological effects such as distress at being unable to feed one's children, insecurity from not knowing where the next meal will come from, and shame at having to go without foods that have strong symbolic value" (World Bank, n.d., chap. 2). When this happens, and as a way of dealing with the situation, one resorts to neglect and sometimes abandonment of their children. The consequences of these acts always render the children vulnerable in one way or another.

Neglect is seen and defined in different ways by different scholars. According to Wilkinson and Bowyer (2017), neglect "is a serious and pervasive form of maltreatment that occurs across childhood and adolescence with potential long-term consequences across the life span" (p.21). Neglect is also "failure to provide for a child's basic needs physically, medically, educationally, or emotionally" (Dryden, 2009, p.4). Abandonment on the other hand is the "means by which a child has been deserted by the parent, guardian or care-giver, or who has, for no apparent reason, had no contact with the parent, guardian, or care-giver for the period of at least three months" (Blackie, 2014, p.7). Murtala and his siblings, especially Imatum, are affected greatly due to their father's neglect and later abandonment. The father, being poor and having a low salary, is unable to take care of his children such that he fails to know and understand what they want and need. In addition to that, he is very neglectful of the children such that he only gets to know about some of the things they do later. Even when he knows, he does nothing to alleviate the situation.

Imatum goes into prostitution due to poverty and neglect from her father. After she goes back to the village with her mother and other siblings, she finds it very hard to adapt as things are not as her mother had said they would be. Hence, she goes back to Kano. Instead of caring about his daughter and trying to find her a school, the father does nothing. When her mother comes back from the village, she only sees her daughter at night when the younger woman comes back from wherever she might have been. From Murtala's description, it is obvious that Imatum earns her money through selling her body. Apart from prostitution, Imatum also starts going to a new church and does not listen to her mother when the older woman reprimands her. When her mother reports Imatum to her father, he does nothing. Rather, he tells his wife that he does not intervene in such trivial issues as church problems. In this case, it can be said that he does not care about his daughter's life or what is becoming of Imatum. In a way, this gives Imatum the licence to behave as she pleases. It is thus left to Murtala to do something about the situation. This is what I read as becoming a man in a 
child's body. My argument here is that Murtala assumes the responsibilities of a parent while he is still a child and while both his parents are living and very much capable to raising their children properly.

As expected, Imatum falls pregnant. When her mother asks her to mention the father of her unborn child, she only keeps quiet. This angers the older woman who threatens to beat her up. The threat only leads Imatum to run away from home. When her father comes back from work, and he is told of Imatum's pregnancy, he does nothing about it. He only asks about Imatum a week after she had run away from home. This attests to the fact that Murtala's father is so uncaring and negligent of his children's well-being. Furthermore, his behaviour totally changes since he keeps to himself and even the children fail to talk to him properly. The father's condition is a constricted one. According to Herman (1992) constriction is the "withdrawal from others, numbing of the self so as to separate from intolerable pain, uncontrollable rage, or intense terror, a narrowing of perception, and an impoverished life" (p.199). Though at first it is not known why the father is traumatised, we soon learn why he keeps to himself: he has recently lost his job, which leads him to disappear from home without a trace. In her study of unemployed males, Griffin suggests that "unemployment could threaten the stability of a traditional masculine identity constructed around discourses such as bringing home a wage and freedom from the domestic sphere" (as cited in Mac Ghaill, 1996). Thus, it can be noted that Murtala's father feels that his ego as the head of family has been bruised by being dismissed from work. Hence, the only way is to run away from his home in order that he clings to his manhood and come to terms with this trauma. In this way, "the failings of customary masculinity are demonstrated by the physical and psychological collapse of Murtala's father" (Osha, 2012, p.1). The sad part is that this collapse, which leads to his eventual desertion of his family leaves the family with so many unanswered questions. In fact, they start a nightly praying vigil for him so that he comes back home. This makes Murtala to stop going to school and he assumes the headship of the family as his father is nowhere to be seen. As the narrator says,

$\mathrm{Ola}^{1}$ came to my house. 'I'm worried that you have not been in school for some days. The exams are coming.'

Is your mum at the market?

\footnotetext{
${ }^{1}$ Ola is Murtala's friend at school. He comes from a wealthy family, whenever necessary, he supports Murtala with some of his basic needs.
}

ISSN: 2456-7620
'No she's gone to see a friend. She's not been going to the market these days.'

'And your dad?'

'It's because of him that I've not been regularly in school.' Ola was wide-eyed. 'What happened?'

'We've not seen him for a week now. We don't know his whereabouts.' I narrated to Ola his sacking from the police force and his strange behaviour, how I found him at the cemetery and his subsequent disappearance without a word. (Sule, 2012, pp.239-240)

The incident, we learn, leads to his mother demanding him to stop going to school completely so that he is able to help her solve the problems at hand. Murtala is here being treated as an adult, even though he is only a boy. The situation that Murtala finds himself in confuses him so much. He is so unsure of his future and wishes his brother, Ukpo, were alive. It is not surprising that he begins to have nightmares:

Sleep eluded me. Where was my life heading? The fear of Mama suddenly taking a decision that would prevent me from writing the JSSCE gripped me. I knew she could suddenly make a decision any day, any minute. If only Baba had not disappeared. Where could he be now? What was he doing now? Did he have a place to lie down and sleep?

If only you were here, Ukpo. Now I need you to be by my side, to give me your knowing grin and to lend your voice to what I feel. If you were here, we would have together sought answers to the mystery of baba's disappearance. Two heads would have made this burden lighter to bear. (Sule, 2012, p.245; original italics)

Here, Murtala is so traumatised. His father's disappearance and the responsibility he has been forced to assume lead to him being depressed and unable to know what to do. There is just too much on his head that he cannot deal with on his own. This is also what Bloom (1999) means in her observation that "children who suffer disrupted attachments may suffer from damage to all of their developmental systems, including their brains, and are particularly ill-suited to having the people they are attached to" (p.2). This is precisely what happens to Murtala. His life drastically changes and his father has ruthlessly broken off all the attachment he had had with his son, wife and the other children when the older man abandons them. 
To further worsen things, a riot breaks out and once again Murtala and his family are forced to seek shelter and protection at the police. While there, Imatum shows up with her Muslim husband and baby to get her mother and siblings to her house. However, the mother refuses to acknowledge her. She also refuses to let any of her children go with her daughter. Later, Ola comes with his father and persuades Murtala's mother to stay at their home. While at Ola's house, his mother decides to take her family back to the home village. Murtala is told that he is coming with them, thereby making him unable to sit for his Junior Secondary School Certificate Examination (JSSCE). Murtala's mother constantly refers to him as "the rational one" and this has a huge bearing on how she treats him especially after the disappearance of her husband. Adekoya (2012) argues that "a name is an image and a metaphor. It not only gives the identity of a person or an object but it is also a representation of the person or the object" (as cited in Adegbite, Adekoya \& Adegoju, 2012, pp. 368-369). This is also what we notice here. Being called "the rational one" forces Murtala to behave sensibly at all times such that he is taken advantage of especially by his mother. In the end he suffers a lot due to this.

At his house, Ola's father tries to reason with Murtala's mother not to take the children to her home village. However, the host's pleas fall on deaf ears. In fact, Murtala's mother stubbornly refuses to go back to the village without her eldest surviving son. The whole situation renders him helpless and it is mostly due to his father's disappearance, much as it also concerns the riots happening in the country. Had his father not abandoned them, things would have been different. Having been left alone to fend for her children and with the instability in the city, the mother does not think of how Murtala is affected by her decision to go back to the village. Much as Murtala is distressed with his parentification, the state of instability he, his mother and siblings are in is heightened by ethnoreligious violence taking place in their community.

Violence per se is an instance of physical force usually effecting or intended to effect injuries. Violence also means "unjust, unwarranted or unlawful display of force, especially such as tends to overawe or intimidate" (Hanks, 1971, p.1617). Arblaster (1975) argues that "violence, other than imposition of physical harm and suffering and death, may also be described as depriving people of food and schooling" (p.239). Additionally, Arblaster also includes poverty as a mode of violence. This violence is experienced in different ways. Some of it is vertical whilst the other is horizontal. Vertical violence is the use of state power to oppress or colonise people. "It is manifested through state policies and the supremacy of the ruling power which curtails the economic, political and cultural freedoms of the oppressed" (Duffy, 1995, p.8). This in turn results in horizontal violence, defined by Harcombe (1999) as "behaviour associated with oppressed groups and can occur in any arena where there are unequal power relations and one group's self-expression and autonomy is controlled by forces with greater prestige, power and status than themselves" (p.40). It is also the inappropriate way oppressed people release built up tensions when they are unable to address and solve issues with the oppressor. Horizontal violence is basically systematic oppression. In Sterile Sky, there are many aspects of this violence. Most of these aspects are ethno-religious in nature. According to Salawu, (as cited in Fawole \& Bello, 2011, p.211)

Ethno-religious conflict essentially, is a situation in which the relationship between members of one ethnic or religious group and another of such group in a multi-ethnic and multi-religious society is characterized by lack of cordiality, mutual suspicion and fear, and a tendency towards violent confrontation.

Sadly, those affected badly are the innocent, especially children. Violence in Sterile Sky is portrayed from the first page. As Murtala is coming back from school, he witnesses the burning of houses and the killing of people by a chanting Muslim mob:

I sighted a chanting mob. Some had their fists in the air. Others wielded swords, spears and cutlasses. They were drawing closer. I turned and headed towards the station, looking back now and then. A clashing sound made me trot. At the station, I turned and saw thick smoke surging upwards behind the mob. A kiosk with Reinhard Bonnke's posters pasted on it caught aflame.

'God almighty! God almighty! Jesus Christ! Help! Help! My body o!' A female voice was shrieking in the burning kiosk. Loud and piecing. It pitched above the mob's chants and died down gradually. Nobody went near the kiosk as the fire razed it. (Sule, 2012, p.1)

It can be seen here that the act of violence is very prominent as innocent people are being killed just because of their association to Christian beliefs (e.g. the woman in the kiosk). Sule seems to draw on what actually happened in history - the clash between Christians and Muslims - as material source of his novel. In October of 1991 in Kano, the Izala sect initiated a peaceful procession to halt Rev. 
Reinhard Bonnke, ${ }^{2}$ a German evangelist, from having a crusade there. This move degenerated into a very bloody religious violence leading to the loss of many lives. Property valued at millions of Naira was destroyed (Onwumah, 2014, p.2). This is also what Sule says through the character of Murtala:

What did the strange man do? He simply said a kind word to one of the blind beggars in front of the palace, where upon the beggar jumped with a shout of joy, his sight restored. The white man would have been stoned to death right there by furious unbelievers who claimed he had brought an evil ring from India to hoodwink all of Kano city. But the emir begged passionately that, for diplomatic reasons the miracle maker should not be killed. (Sule, 2012, p.2)

The unbelievers and non-Christians feel that Rev. Bonnke is some sort of magician and do not wish their city to be trapped by his magic. As such, they start a riot with the aim of immobilising everything. The problem is that it is innocent people who face the consequences of the wrath of these non-Christians led by the Muslims. According to Coser (1956, p.99)

conflict occurs when two or more people engage in a struggle over values and claims to status, power and resources in which the aims of the opponents are to neutralize, injure or eliminate their rivals. He further explained that conflict emerges whenever one party perceives that one or more valued goals or means of achieving these valued goals are threatened or hindered by another party or parties or by their activities.

In this case it can be said that the ethno-religious conflict is merely a struggle of power between the warring sides, which are the Hausa/Fulani-Muslims and Igbo Christians. However, they try hard to find a scapegoat as a way of blaming it on someone else instead of accepting responsibility. That said, it can be seen that despite this riot

${ }^{2}$ Reinhard Bonnke is a German pastor born on 19th April, 1940. He studied at the Bible College of Wales in Swansea in 1967. In 1986, he established the Church for all Nations and he focused mostly on Africa and Nigeria in particular. In 1991, he went to Nigeria and Muslims protested over remarks he had made about Islam in the city of Kaduna on his way to Kano. A rumour was spread that Bonnke was planning to lead an invasion into Kano. Muslim youths gathered at the Emir's palace and after noon prayers, the riots ensued, during which many Christians sustained various injuries and several churches were burned. being connected to Rev. Bonnke, the riots seem to be recurrent. This can be confirmed through the prayer by Murtala's mother. According to Murtala, his mother prays to God to preserve their lives as He did before: "Mama broke the silence. 'Jehova our Lord, we're in your hands. You've saved us from riots before. Save us from this", (Sule, 2012, p.7). The last time the killings happened, their house (and that of their neighbour's) was spared. This time, the killers are all over the neighbourhood. This is attested by the fact that the killers murder all the occupants of the houses surrounding their house before they move on to theirs. For instance, the narrator points out that the killers reach Murtala's neighbour's house where they murder everyone and even cut open the womb of Helen's pregnant mother because they believe the unborn child will be a "kaffir" Christian. (Sule, 2012, p.10). The use of the word "kaffir" brings to mind the racist sentiments often uttered by people who feel that their race or religion is far more superior than that of the other person. This is also how the persecutors behave. As enemies of the Christians, they do not want to witness a new generation of Christians being born to cause trouble for them. ${ }^{3}$ Thus, to control this and prevent it from happening, they cut the woman's womb thereby killing the unborn child. Murtala is greatly affected by this because Helen is his girlfriend and hearing her voice as she is being beaten weakens him. As the narrator says,

'I moved away from the wall. I picked out Helen's voice, raw, responding to each blow. Tears stung my eyes. I felt the pain of being clubbed to death. I felt as light as a leaf.'

'Hold him! Hold him! Hold my son for me,' I heard Mama's voice distantly. I felt Baba's hands around me, pulling me up. 'Murtala,' he

\footnotetext{
${ }^{3}$ Ethno-religious conflicts and violence in Nigeria date back to British colonial rule after the conquest and partitioning of what would later become the protectorates of Northern and Southern Nigeria. Nigeria was born out of the amalgamation of the two protectorates in 1914 with little or no regard at all for the ethnic groupings. The partitioning, however paved the way for separate developments among various ethnic units. This form of division was mainly for hey resorted to the employment of the callous and infamous principle of "divide and rule." 5 . Thus, upon the attainment of political independence, Nigeria was a state already fragmented along ethnic, religious, linguistic and political lines. Therefore, when after only six years of independence a civil war broke out, it was germination of the seed of acrimony and intolerance that was planted in 1914. (Bashir Alhaji-Shehu, 5), (Onwumah, 126)
} 
called softly, his lips against my left ear. He called again. I responded. He dragged me near to Mama. In that half-conscious state, I saw Mama's body quiver uncontrollably. I screamed. A heavy palm clamped over my mouth and the scream filled my mouth. I jerked violently, struggling for breath [...]. Baba said, 'You must remain quiet. Don't scream!' (Sule, 2012, p. 9)

It can be seen that Sule conveys the precarious state of Murtala's family which is symbolic of many poor families that fall prey to the instability and other horrendous experiences caused by intolerance leading to violence. Many are in a state of fear and panic as portrayed by Murtala's family. The family members are not even sure if they will survive. This is so since after killing the occupants at Helen's house, the killers move to Murtala's house. This is similar to what happens in After they Left by Edify Yakusak (as cited in Ogundipe, 2018, p.138). This text begins with a scene where people live in "fear and apprehension of a looming danger, through detailing the sound of a mob action: 'the sound of terror' is chanted around the neighbourhood" (Ogundipe, 2018, p.138). This is precisely what happens at the beginning of Sterile Sky where a chanting mob is also heard. Mafeng, the protagonist of After They Left hides in her house together with her husband and two children at the sound of the looming danger:

The two children are quickly thrown into the water tank, while the husband and wife find solace underneath the bed. They locked their door, but the door was useless against the wrath of the mob; "two gunshots wrecked the lock and they poured in, thirsty for blood" (16). Apparently, the mob knew that the family was inside. At the end, the mob killed Samuel, the husband; and his wife, Mafeng, was raped until she was unconscious. (Ogundipe, 2018, p. 139)

The description in the passage above is similar to what occurs in Sterile Sky as Murtala's family also hides in their house upon the inception of the killings. This simply shows the propensity of hatred propelling the killers. Just as Mafeng and her family are hiding from the killers, Murtala and his family also do the same and his mother even murmurs a prayer for protection from the approaching killers. In the words of the narrator,

As if Mama's prayer had invited them, we heard a loud bang on our door. Yakubu dashed out of the latrine, holding his shorts in his left hand, watery shit dripping from him. Baba sprang up and Mama froze awkwardly. Imatum and Ajara and Anyaossu held one another tightly. They wept silently. Oyigwu and Emayabo burst into fresh tears. I tried to stand up, but my legs could carry me no longer. The hour has come [...]. (Sule, 2012, p.11)

The storytelling is very palpable in the narrative and one can easily observe that Murtala seeks out ways of blocking the memories that are characterized by the struggle to both remember and forget due to their graphic nature and the feelings they evoke in him. There is what LaCapra (1999, p.65) calls an aspect of "absence" in the way Murtala's family responds to this trauma. There is a "sense of traumatic hurt" (LaCapra, 1999, p.65) resulting from the family's inability to grasp their signification from one another. It is not surprising that Murtala accepts and awaits the inevitable by stipulating that "the hour has come" (Sule, 2012, p.11). He only sees death as the only outcome given the circumstances that his family is in. The expression "the hour has come" has some biblical connotations. In Christian mythology, this alludes to the time when the Passover was fast approaching and Jesus Christ knew that the time had come when he had to die for the redemption of mankind. Hence, as a way of accepting the inevitable, Christ said 'the hour has come' several times (see Mark 14:41, John 12:23-24, and John 17:1) to signify the agonies he was to go through and the eventual crucifixion on the cross. In Sterile Sky, it can be seen that Murtala's family is in a state of fear due to the situation at hand as everyone around them is being murdered and the killers are nearing his house. Like the biblical Christ therefore, Murtala's family accepts the inevitable even though it is agonising. Hence, the allusion in the passage above is used to enhance the painful condition of Murtala and his family. It also symbolises the acceptance of an imminent negative situation. This is in line with what Herman (1992) stipulates, that "traumatic reactions occur when action is of no avail. When neither resistance nor escape is possible, the human system of self-defense becomes overwhelmed and disorganized" (34). This is what happens with Murtala's family. Before leaving for the police shelter, there seems to be no hope that they will escape the wrath of the killers and they become overwhelmed with their predicament and can only accept the inevitable. The imagery of Yakubu, Murtala's younger brother "dash[ing] out of the latrine, holding his shorts in his left hand, watery shit dripping from him" (Sule, 2012, p.11) clearly emphasises the terror and hopelessness of the 
situation. No one can hear the other let alone think about the 'shit' as everyone is thinking of survival.

When all hope seems lost, the barber shop owner comes to the rescue of Murtala's family. He lies to his fellow Muslims that the family has already fled and the house is under his care. As such, it should not be burnt down. Murtala's family is thus saved by grace. While all this is happening, the sky becomes sterile and lifeless, which is symbolic of the situation at hand. Just as the sky looks lifeless, so too is Murtala's family. It looks helpless and has no power or ability to save itself from the killers. If it were not for the barber shop owner, the entire family would have been wiped out. Therefore, it can be noted that the barber shop owner, is an advocate of peace and goodwill. He is different from the other 'neighbours' (people of other ethnic groups and religion). Zizek (2008) observes that, "a neighbour could pose a threat to the internal psyche and the very core of personhood of another because of the proximity" (59) and because a neighbour could be a "' 'traumatic intruder,' one then should fear the neighbour" (Zizek, 2008, p.59). We get the opposite of what Zizek says here, since the barber shop owner in Sterile Sky, who fits Zizek's description of "a neighbour [who] poses a threat" to those around him, is seen protecting Murtala's family even though they belong to different religions. This then entails that people fight in the name of religion just to justify their fighting. In the narrative context of the novel, this has made the nature of social relationships within neighbourhood interactions in the urban areas in Northern Nigeria to be volatile. Yet through people like the barber shop owner, we can say that in the midst of the violence, there are others who wish for tolerance and harmony, and do what they can to achieve that even if they do it all alone. Such people do not abuse and misuse ethical values, religious beliefs, traditions and symbols. Rather, they embrace them.

Later, the family takes refuge at the police station. On its way there, it witnesses the carnage caused by the killers. As the narrator says, "I noticed that the road was littered with corpses. I could also see many damaged cars and motorcycles. Some houses by the roadside smouldered with acrid smoke. We walked in silence. Inhaling the stale odour of death" (Sule, 2012, p.13). At the police shelter, they meet more families who had also run away from the killings. Hearing about the loss each family has suffered leads Murtala to become violent. Later, he loses his younger brother to an accident, an incident that shatters him for life. His mother, too, is affected by the loss such that she decides to go to the village to ensure the safety of her children. However, Murtala chooses to stay behind with his father while all his siblings leave with his mother.
It can be seen here that the older woman is "devoted to the care of others; she is self-sacrificing and not a subject with her own needs and interests" (Fombele 2015, p.194). Unlike the father, the mother wholly thinks of the safety of her children and behaves accordingly.

When the riot finally subsides, Murtala goes back to school where he hears so many horrendous tales about the riots. We learn, for example, that the school has lost twenty-four students. As prayers are being offered to remember the departed, Murtala feels disoriented. This is because he feels bitter that the leaders are using the same religions that led to the death of his brother, Ukpo, and his friend Helen. The riot affects most of Murtala's classmates, except Ola who, in the narrative context of the novel, stays near the governor's house in a place called Government Reserved Area (GRA) and only knows about the killings through television. The fact that Ola's house is politically situated near the governor's house says a lot about the nature of the narrative. Autor et al (2005) observe that "places are stratified along a hierarchy, with the affluent occupying the most resource-rich neighbourhoods and these enjoy a number of social advantages such as safety, high quality schools, and political power" (p.205). It is no wonder that most of the people living in the GRA are those with affluence and live quite a stable and protected life which is sheltered from most of the viciousness life can bring. This is totally different from the poor neighbourhoods where the inhabitants suffer from "disinvestment, deteriorating physical structures, increased crime, and lack of political power" (Briggs, 2005, p.230). That is why only the poor and those living in unstable locations are the ones who are affected when violence breaks out and gets ugly. It also implies that the security of the many urban spaces is very poor. The rich and well-known people are the ones who are secured and protected from various kinds of crises, unlike the many poor who are left to fight for their lives when conflicts get out of hand.

It is no wonder then that when another riot breaks out, the poor, unstable people are forced to go back to the police shelter. This time around, Murtala is the one acting as the head of his family as his father has disappeared without a trace. He is forced to be in a liminal state due to circumstances beyond his reach. According Gennep (1960) "liminality expresses the ambivalent state of the initiand or the same 'transit-traveler', his transition to the intermediate, ambivalent social zone, the so-called "limbo"' (cited in Ratiani, 2007, p.1). What this means is that an individual is in a "betwixt and between" situation. Often, liminality comes as a result of a person's conscious choices, but it is possible to have liminality thrust upon one. For example, sexual violence and the consequent 
pregnancy is a liminal status that is forcefully thrust upon a person. This is somewhat similar to Murtala's case. Responsibility is thrust upon him despite his tender age, thereby rendering him to be in a liminal state. Turner (1982) sees liminal periods as both "destructive" as well as "constructive," since "the formative experiences during liminality will prepare the 'initiand' to occupy a new social role or status, made public during the reintegration rituals" (p.88). In the case of Murtala, this period is destructive. This is so because the responsibility thrust upon his shoulders bears on him a huge weight that is not only beyond his young age but also threatens the completion of his education. He is being forced to transform from a boy to man due to his experiences.

At the shelter, Ola comes with his father who offers Murtala's mother and her children a home at their place. Murtala's mother only accepts out of persuasion from Ola's father. But then, she does not stay long at Ola's house. She decides to go back to the village, insisting on taking Murtala with her. She does this because she feels displaced and cannot identify with town life anymore. She can no longer call that place home. When she came back from the village, she believed that things would change for the better. However, they just got worse. Thus, this displacement can be said to be both metaphorical and physical. Compared to town life, village life is a better option for her and a place of regeneration. Accordingly, it is symbolic of cultural rebirth. Needless to wonder, she does not want to leave Murtala behind.

Duncan and Gregory (1999) observe that "the journeys taken by the travelers, regardless of the motive, transforms the personality of the traveler" (1). This is also true with what happens with Murtala. Through his experiences and movements, he discovers new realities about his own identity, society and life. What this means is that through his experiences, he has learnt what his identity as a poor person entails in the society he lives and what he has to do to change his status. As a character, he literally moves from one place to another, regardless of destination in order "to discover and learn essential truths about himself, his society, and the nature of human existence" (Howard, 2010, p.7). Hence, this literal act of moving which involves passing through unfamiliar areas where Murtala as a character faces and solves problems and hardships encountered along the way brings about a symbolic significance in the journey motif as it can be noticed that the journeys have a figurative implication. In this way, it can be said that the various journeys Murtala has undertaken have enabled him to see life with fresh eyes. He is enabled to change how he perceives his father as well as fully understand the predicament the older man is in. His journeys, thus, become a catalyst for change and knowledge to him and also his whole family. Though it ends in suspense, it can be said that Murtala is geared to better his life through thick and thin to get out of poverty. He has to find a way to be better. This is unlike what happens in Achebe's (1958) Things Fall Apart, for example, where the protagonist, Okonkwo, is forced to leave his native land for his motherland after he commits an abomination when he inadvertently kills a clansman who is the son of the late Ezeudu during the deceased's funeral ceremony (93). When he returns seven years later, he finds that things have changed. His failure to adapt to the changes results to some extent in his tragic downfall. Unlike Okonkwo, Murtala's experiences help him to fully understand the gravity of his situation which shape him to wish to be better. Moreover, his experiences help him to also undergo a psychological journey (on top of the physical one) to responsible manhood as he assumes the role of a parent and takes care of both his mother and siblings especially after his father's desertion.

Murtala is disturbed as his JSSCE examinations are imminent and his father is still missing. This troubles him so much that before embarking on the journey back to the village, he is determined to find his father. He is concerned about the health of his father. He also wants to plead with the older man to help talk to his mother to leave him behind until he sits for his examinations. Lucky enough, he has a dream where Ukpo leads him to where their father is. Since the dream is so vivid, Murtala decides to go and look for his father and finds him. Murtala is overjoyed at seeing his father again and believes that the older man will come back with him. To his surprise, Murtala's father refuses to go back with him, saying he has found freedom. He tells his son to let his mother know that he has "begun a new life" (Sule, 2012, p.284). His "previous life was one long sleep" (Sule, 2012, p.284). He does not care at all as to how the wife and children are faring after he abandoned them. In fact, the father does not regret abandoning his family. To prove this, he tells his son that once he leaves, he will go to another place and they do not have to bother to come looking for him anywhere. This simply shows the extent to which this man has neglected his responsibilities. He cannot even think of how his son is being affected due to his abandonment of him and the responsibility he (Murtala) has been forced to carry. This breaks Murtala's heart as he knows that the possibility of him sitting for his examinations is fading away and there is nothing he can do about it. Instead of Murtala's burden being eased, it is increased. He feels so helpless, hopeless, defeated.

Regardless of his distress, Murtala is ambitious and visionary. He resolves to run away when they go back to 
the village so that he can continue with his education. He is so determined to do well and get out of the poverty trap. He says this as much to Ola: "Please tell your dad I'll escape to Kano to continue my schooling. I will return" (Sule, 2012, p.276). This kind of agency in Murtala shows that through his bad experiences, he has found a reason to become someone in life and he is more determined than ever to achieve just that. Agency is the ability for one to make a choice regarding the experiences he or she undergoes. One would think that Murtala would just accept defeat and let destiny take care of itself. On the contrary, this is not what he does. The need to get out of the poverty trap propels him to go forward and be optimistic. What looks like a barrier becomes an opportunity for him to prove himself.

This is not the first time for Murtala to resolve to do well rather than just give up. Instead of feeling sorry for himself due to his experiences as a child born in a poor family, he decides to do well no matter the disappointing circumstances. Earlier in the novel, before his father had abandoned them, and soon after his sister Imatum had returned to Kano, he had made a similar resolve. Murtala had found Imatum at their new home at Kwanar Jabba in Kano state. As they were chatting, Imatum had told him that she was going to marry a rich man and not a poor man like their father and Murtala himself. Murtala had declared to his sister that he was not going to be poor like their father. Rather he would go to university and become a medical doctor. Here, it can be seen that even though Murtala's father is poor, and the living standards are very bad, Murtala hopes for a better life for himself. He wants to get an education so that he escapes the throngs of poverty he is facing. Before then, he had stumbled upon his father beating his wife. His mother is taken to hospital where Murtala imagines himself as a medical doctor treating his parents and siblings:

I imagined myself as a doctor, a medical director, with my own hospital. I imagined myself coming into my hospital, the patients standing to greet me. I shook hands with them and asked them about their work and their families, about SAP and the activities of the military president. I imagined myself treating Mama and Baba and my siblings. I pictured myself making money and lifting Mama and Baba out of poverty. (Sule, 2012, p. 156)

All these are signs of someone who is determined to get his family and himself out of poverty. Thus, it has to be noted that each time Murtala undergoes a discouraging situation either as a victim or a witness, he is motivated to work hard and become someone in his life. Rather than reacting negatively to this stimulus, he does the opposite. He is determined and optimistic.

\section{CONCLUSION}

This article has presented some of the ways in which notions of emotional abuse and ethno-religious violence play out in an African context. It has depicted how some children like Murtala are parentified due to abandonment coupled with violence thereby putting them in a precarious state. Parentification is often overlooked by people and is not mostly regarded as a form of abuse. However, this kind of thinking has been problematized in this article through the experiences that the protagonist goes through in Sterile Sky. Murtala becomes a man in a child's body, leading him to becoming a liminal being. As if what he goes through is not enough, he lives in that part of the city which is so unstable due to ethno-religious conflicts that see him (and his family) moving from one place to another in search of a safer dwelling place. It has to be noted that the experiences Murtala face are as a result of having poor parents. Murtala's life is full of instability and misery, unlike his friend Ola's. Ola comes from a rich family and none of the ethno-religious crises taking place in the country affect him. In fact, his father is a Christian whereas his mother is a Muslim. Still, they live together in harmony. Ola's family is thus symbolic in the sense that Sule is perhaps trying to put across the message that some people may choose to fight in the name of religion or ethnicity while others can live in harmony with each other. Another example is Imatum, who is Murtala's sister. She is a Christian married to a Muslim. These family dynamics show how possible it is for different religions to coexist. Since both Imatum's husband and Ola's parents are rich, it can be said that it is easier for the rich to interrelate than the poor since it is the latter that are faced with the hardships of life. Hence, Murtala's agency in what he wants his future to look like is determined by all these situations as he begins to see life through a different light.

\section{REFERENCES}

[1] Achebe, C. (1958). Things fall apart. Heinemann.

[2] Adebare, O. (2013, January 15). "Sterile sky by Egya E. Sule: A review." https://Africabookclub.com/sterile-sky-byegya-e-sule/

[3] Adegbite, W., Adekoya, S., \& Adegoju. (2012). Use of English: A manual on communicative skills for tertiary institutions. Olas Ventures. 
[4] Alhaji-Shehu, B. (2012). Ethno religious conflicts/ violence in northern Nigeria (Master's thesis). Wien University.

[5] Arblaster, A. (1975). "What is Violence?" The Socialist Register, 12, 224-49.

[6] Autor, D.H., Katz, L.F., \& Kearny, M.S. (2005). "Trends in U.S wage inequality: Reassessing the revisionists.' NBER WORKING PAPER SERIES, Working Paper 11627.

[7] Blackie, D.E. (2014). Sad, bad and mad: Exploring child abandonment in South Africa (Unpublished master's thesis). University of Witwatersrand.

[8] Bloom S.L. (1999, October). "Trauma theory abbreviated." From the Final Action Plan: A Coordinated Community Response to Family Violence, 1-17.

[9] Briggs, X.S (Ed.) (2005). The Geography of opportunity: Race and housing choice in metropolitan America. Brookings Institution Press.

[10] Coser, L. (1956). Functions of social conflict. The Free Press.

[11] World Bank. Definitions of poverty. (n.d). siteresources.worldbank.org.

[12] Dryden, K.M. (2009). Child abuse and neglect: A resource guide (Master's thesis). University of Wisconsin Stout.

[13] Duffy, E. (1995). "Horizontal violence: A conundrum for nursing. Collegian." Journal of the Royal College of Nursing Australia. 2(2), 5-17.

[14] Duncan, J., \& Gregory, D. (1999). Writes of passage: Reading travel writing. Routledge.

[15] Engelhardt, J.A. (2012). "The developmental implications of parentification: Effects on childhood attachment." Graduate Student Journal of Psychology, Teachers College, Columbia University, 14, 45- 52.

[16] Fawole, O.A., \& Bello, M.L. (2011). "The impact of Ethnoreligious conflict on Nigerian Federalism." International NGO Journal, 6(10), 211-18.

[17] Fombele, E. (2015). "Mothering: A discursive strategy in your name shall be Tanga." Cameroon Journal of Studies in the Commonwealth, 2(2). University of Buea, Cameroon, 193-202, camerooncommonwealthjournal.com/,

[18] Hanks, P. (1971). Collins English dictionary of the English language. Collins.

[19] Harcombe, J. (1999). "Power and political power positions in maternity care." British Journal of Midwifery, 7(2).

[20] Herman, J. (1992). Trauma and recovery. Basic Books.

[21] Howard, N. (2010). The quest motif in literature: Supplemental handout for English. Fantasy Fiction.

[22] Hooper, L.M., Doehler, K., Wallace, S.A., \& Hannah, J.N. (2011). "The parentification inventory: Development, validation, and cross-validation." The American journal of family therapy, 39, 226-241, Taylor \& Francis Group, https://doi:10.1080/01926187.2010.531652.
[23] LaCapra, D. (1999). "Trauma, absence, loss." Critical inquiry, University of Chicago, 25(4), 696-727. http://links.jstor.org/sici?sici=00931896\%28199922\%2925\%3A4\%3C696\%3ATAL\%3E2.0.C O\%3B2-N

[24] Mac An Ghaill. M. (Ed) (1996). Understanding masculinities. Open University Press.

[25] Ogundipe, S. (2018). "Conceiving neighbourhood in northern Nigerian fiction." Utafiti 13(2), 136-56

[26] Onwumah, A.C. (2014). "Communal and Ethno-Religious Crises and their implications for national Development in Nigeria." Developing Country Studies, 4(17), 126-31.

[27] Osha, S. (2012, October 9). "Slaughtered by religion: A review of E.E. Sule's sterile sky," https:// africanwriters' $c o m$ /slaughtered-by-religion-a-review-of-e-esule-sterile-sky/

[28] Ratiani, I. (2007). "Liminality and the liminal theory of conceptualizing time and space in 20th century: Eschatological anti-utopia." Georgian Electronic Journal of Literature, 1(1), 1-7.

[29] Sule. E.E. (2012). Sterile sky. Pearson Education Ltd.

[30] Tam, O.K.W. (2009). The parentified child in a child psychotherapist: A systematic literature review of the parentified child, exploring its effects on the countertransference process in child psychotherapy (Master's thesis). Auckland University of Technology.

[31] Tagurum, Y.O., Chirdan, O.O., Obindo, T., Bello, D.A., Afolaranmi, T.O., Hassan Z.I., \& Yilgwan, C. (2015). 'Prevalence of violence and symptoms of post-traumatic stress disorder among victims of Ethno-religious conflict in Jos, Nigeria.' Journal of Psychiatry, 18(1), 1-6. DOI:10.4172/2378-5756.1000178

[32] Turner, V. (1982). From ritual to theatre: The human seriousness of play. PAJ Publications.

[33] Wilkinson, J., \& Bowyer, S. (2017, March). The impacts of abuse and neglect on children; and comparison of different placement options. Research in Practice.

[34]Zizek, S. (2008). Violence: Six sideways reflections. Picador. 